\title{
Economic Security and Sustainable Development of an Economic Entity in the System of Transactions With Digital Financial Assets
}

\author{
A. Popov ${ }^{1, *}$, I. Vlasova ${ }^{1}$, R. Holbekov ${ }^{2}$ \\ ${ }^{1}$ Ural State University of Economics, Yekaterinburg, Russia \\ ${ }^{2}$ Tashkent State University of Economics, Tashkent, Republic of Uzbekistan \\ *Corresponding author. Email: prepodpopov@yandex.ru
}

\begin{abstract}
The article reveals the problems of using digital financial assets, substantiates the threats to economic security in the implementation of transactions with them and measures to mitigate risks in order to ensure the sustainable development of economic entities. Based on the analysis of the regulatory framework and various author's interpretations, the definition of digital financial assets has been clarified, the main provisions regarding the circulation of these types of civil rights, including their advertising, have been disclosed. Requirements for operators of specialized information systems in which digital financial assets are issued and for operators of exchange of these assets are formulated. Due to the high level of risk of digital financial assets, a classification of risks in carrying out operations with these types of property based on the subject-object approach is proposed. In order to mitigate threats to economic security, the TARA model has been adapted for operations with digital financial assets. Further directions of scientific research on the problems of using digital financial assets in civil circulation in order to strengthen economic security and implement sustainable development not only of enterprises, but also of the Russian economy as a whole are outlined.
\end{abstract}

Keywords: Digital financial assets, Economic security, Information systems operator, Exchange operator, Risks of transactions with DFA, Risk management model.

\section{INTRODUCTION}

In modern economic conditions, characterized by the digitalization of global economic processes, close attention has been paid to the circulation and use of digital financial assets (DFA) in the economic turnover. At the same time, due to insufficient knowledge and the presence of a large number of issues in the legal regulation of the release and use of digital assets, the practice of their circulation in the economic environment faces a number of problems that need to be addressed in a timely manner. As L.V. Sannikova notes, "digital assets have such features that allow them to be set apart in the system of objects of rights, which entails the need to develop new legal mechanisms of regulation, different from the existing ones, focused on the circulation of objects of the material world." [1] Laptev V.A. [2], Sidorenko E.L. [3], Dmitrieva G.K. [4] addressed the legal essence and legal issues of using digital financial assets in their works and other researchers. Also noteworthy is the foreign experience of using digital assets, described by Barney M. [5], Austerberry D. [6], Koldberg K. [7] and other scientists. The law "On digital financial assets, digital currency" of July 31, $2020 \mathrm{~N}$ 259-FZ, which entered into force on January 1, 2021, approved key provisions regarding the issue, accounting and circulation of digital assets, however, this also gave rise to a number of issues in the practical application of legislative norms. In addition, the use of digital assets by business entities in economic activity generates a number of risks, respectively; special attention should be paid to the issues of ensuring the economic security of entities in the implementation of these operations. The Russian economists A.K. Modenov [8], M.P. Vlasov [9], O.A.Mironova [10], E.S.Mityakov [11], R.V. Dronov, consider general issues of ensuring the economic security of the organization. [12], Krokhicheva G.E. [13] etc. They pay close attention to the issues of ensuring the sustainable development of the organization because of 
strengthening production and economic potential and ensuring financial sustainability, however, ensuring security in the implementation of transactions with digital assets is not adequately covered. These prerequisites determine the relevance of the issues considered in this article and its goal is predetermined the theoretical and practical disclosure of issues of ensuring economic security and sustainable development of an economic entity, when carrying out transactions with digital assets in the context of a general digitalization of the economy.

\section{MATERIALS AND METHODS}

This study was carried out on the basis of the current regulatory framework and a large amount of scientific and practical literature, given in the bibliographic list. To achieve this goal, this study used general scientific and special methods. In particular, description and generalization methods were used to substantiate the definition of digital financial assets. The basic rules for the circulation of digital financial assets are formulated using observation and deduction methods. In developing the risk classification, analytical methods, grouping and comparison methods were used. Recommendations for strengthening economic security and sustainable development of an economic entity in the implementation of transactions with CFA are formulated using abstraction and extrapolation.

\section{RESULTS AND DISCUSSION}

To consider the issues of ensuring economic security, it is necessary to refer to the analysis of the definition of digital assets according to the interpretations that take place in domestic science and practice. The study analyzed various points of view of economists, as well as the regulatory framework; the results are presented in Table 1.

Accordingly, in this work, digital financial assets will be understood as digital rights, which certify the following closed list of rights and requirements of the holders of these assets:

- monetary claims;

- the possibility of exercising rights under equity securities;

- the right to participate in the capital of a non-public joint stock company;

- the right to demand the transfer of equity securities, which are provided for by the decision on the issue of digital financial assets.

Law of the Russian Federation No. 259-FZ defines the main provisions regarding the issue, accounting and circulation of digital financial assets, as well as requirements for operators of information systems and their activities, which should be briefly discussed in order to disclose problems and develop recommendations for strengthening the economic security of entities and their sustainable development in the digital asset management system.

The decision to issue digital financial assets can be made by a legal entity or an individual entrepreneur and must contain detailed information about the issuer itself, the operator of the information system, the type and scope of rights certified by digital assets, etc. The release of digital assets can only be carried out in a specialized information system (SIS), which contains the relevant records certifying the release, movement,

Table 1. Analysis of the concept of digital financial assets

\begin{tabular}{|c|c|}
\hline Author and source & Interpreting the definition of a digital asset \\
\hline $\begin{array}{l}\text { Laptev V.A. Digital assets as objects of } \\
\text { civil rights // Legal science and practice: } \\
\text { Bulletin of the Nizhny Novgorod } \\
\text { Academy of the Ministry of Internal } \\
\text { Affairs of Russia. - 2018. - No. } 2 \text { (42). }\end{array}$ & $\begin{array}{l}\text { "digital things", "Internet values" or "Internet property", because their existence } \\
\text { and civil circulation are possible in the cyber-physical space using the information } \\
\text { and telecommunication network "Internet". [2] }\end{array}$ \\
\hline $\begin{array}{l}\text { Dolgieva M.M. Digital Assets and } \\
\text { Criminal Legislation of Russia // Legal } \\
\text { Science and Practice: Bulletin of the } \\
\text { Nizhny Novgorod Academy of the } \\
\text { Ministry of Internal Affairs of Russia. - } \\
\text { 2019. - No. } 1 \text { (45). }\end{array}$ & $\begin{array}{l}\text { "a collective concept that includes, first of all, cryptocurrencies, tokens and other } \\
\text { assets, while the main difference between digital assets and digital currencies is the } \\
\text { decentralized nature and the absence of an issuer in the form of a state or bank" } \\
{[14]}\end{array}$ \\
\hline $\begin{array}{l}\text { Dmitrieva G.K. Digital financial assets: } \\
\text { problems of conflict regulation // Actual } \\
\text { problems of Russian law. - 2019. - No. } 5 \\
(102) .\end{array}$ & $\begin{array}{l}\text { "digital codes or designations existing in a decentralized information system, } \\
\text { which certify the rights of the owner of unique access to them for other (" real ") } \\
\text { objects of civil rights, with the exception of intangible benefits" [4] }\end{array}$ \\
\hline $\begin{array}{l}\text { Federal Law "On Digital Financial Assets, } \\
\text { Digital Currency and on Amendments to } \\
\text { Certain Legislative Acts of the Russian } \\
\text { Federation" dated July } 31,2020 \text { N 259-FZ }\end{array}$ & $\begin{array}{l}\text { "digital rights, including monetary claims, the ability to exercise rights to equity } \\
\text { securities, the right to participate in the capital of a non-public JSC, the right to } \\
\text { demand the transfer of equity securities, which are provided for by the decision on } \\
\text { the issue of CFA, the issue, accounting and circulation of which is possible only by } \\
\text { making (changing) records in an information system based on a distributed } \\
\text { register, as well as in other information systems " }\end{array}$ \\
\hline
\end{tabular}


ownership rights and other information in relation to the issued DFA.

The operation of the information system, in which DFAs are taken into account, is ensured by its operator, to which the following requirements are imposed:

- possession of the necessary competencies and actual capabilities for the development and maintenance of the information system infrastructure;

- the presence of a significant margin of financial strength;

- the manager, members of the collegial executive body, the chief accountant and the head of the internal control service must have higher education and work experience in the relevant areas, and also have no outstanding criminal record.

The SIS operator must be included in the register maintained by the Bank of Russia.

Further circulation of digital financial assets is carried out by concluding appropriate transactions between participants in economic turnover, which are registered by a specialized entity - the operator of the exchange of digital assets, whose functions include collecting, comparing, and executing diverse requests from asset holders for their exchange. In addition, the exchange operator can participate in transactions with the CFA as an attorney in the interests of third-party entities, but at their own expense.

Special requirements are also imposed on operators of the exchange of CFA, and the Central Bank of the Russian Federation maintains a separate register of them. The subjects included in the register of exchange operators of the CFA may be banks and other financial and credit institutions, exchanges and other trade organizers, as well as other legal entities that meet the following requirements:

- $\quad$ the primacy of Russian legal norms and their use as the personal law of a legal entity;

- the minimum amount of the authorized capital must exceed the threshold value - 50 million rubles;

- the minimum amount of assets of an economic entity free from third-party obligations (net assets) must exceed a similar threshold size - 50 million rubles;

- founders and other participants should not be registered in so-called offshore zones, which make it possible to apply preferential tax regimes and not disclose information about financial transactions;

- $\quad$ the presence in the structure of management bodies of the supervisory board or other body exercising internal control and risk management; confirmed qualifications of executive bodies, chief accountant, head of the internal control service;

- the share of founders who have violated the legislation of the Russian Federation in relation to financial and economic transactions should not exceed $10 \%$.

The rules for the exchange of digital financial assets, as well as the maintenance of registers of operators of information systems and operators of the exchange of digital assets, were approved by the Regulation of the Bank of Russia No. 746-P of 12/16/2020. These rules prescribe:

- principles and procedure for registration of transactions with CFA;

- a list of DFAs, operations with which are performed by the specified exchange operator;

- principles of operations between operators of specialized information systems that issue DFS and operators of their exchange;

- ensuring the necessary requirements for the protection of information and the reliability of operating systems;

- a list of possible cases when transactions with CFA must be executed regardless of the receipt of a corresponding request from the holders (for example, by a court decision).

With regard to a number of digital assets, the Bank of Russia makes it possible to carry out transactions with the latter only to qualified investors, by which, in relation to legal entities, are meant entities that meet a number of criteria:

- the presence of equity capital of at least 200 million rubles;

- the volume of transactions with securities concluded in the last four quarters - at least 5 times for each quarter and more often than once a month, and the total contractual value of transactions should not be less than 50 million rubles;

- the revenue of an economic entity, calculated in accordance with FSBU 9/99, should not be less than 2 billion rubles;

- the balance sheet total for the last reporting year exceeds 2 billion rubles.

Also, the Bank of Russia can set a limit for transactions with CFA unqualified investors.

With regard to advertising of digital financial assets, Law 259-FZ establishes specific requirements, which include the obligation to indicate a high degree of risk of transactions with digital financial assets, the maximum possible amount of digital rights acquisition, an indication of the issuer and operator of the SIS, etc. 
Since activities with digital financial assets, even at the legislative level, are recognized as highly risky, we will dwell on these risks in more detail, since their avoidance will strengthen the economic security of business entities and ensure their sustainable development. Gorulev D.A. notes that "economic security in the digital economy is gaining increased importance due to the fact that the movement of real assets is accompanied by digital media and channels in their various forms, and due to the fact that the very essence of production and, in the future, social and economic In these conditions, various abuses will appear and manifest in the economy, the suppression of which should be dealt with by specialists in the field of economic security, which, in our opinion, will be more and more in demand. "[14]

In the course of the study, we considered various classifications of risks proposed by domestic and foreign researchers, but the scope of this work does not allow us to reveal in detail the general classification of risks. We will highlight only the main factors of the general classification of risks, which are:

- time of occurrence (retrospective, current and subsequent risks);

- categories of the main risk factor (political, economic, market, financial, reputational, environmental);

- the nature of accounting (internal and external risks);

- the nature of the consequences (pure and speculative risks);

- scope of activity (production, commercial and financial risks).

At the same time, we have identified subject-object relations as a key feature of risk classification of transactions with digital financial assets. As a result of the analysis, we propose the classification of the risks of transactions with CFA presented in Table 2.

The risks of the most digital financial assets are determined in accordance with the general concept of risks characterizing financial investments in accordance with PBU 19/02, since by their nature digital financial assets most closely correspond to this category, since their ownership generates corresponding benefits for the entity.

The risks of the issuer of digital financial assets are summarized in accordance with the previously formulated concepts of the risks of economic entities, proposed, in particular by prof. Bezdenezhnykh V.M. [16], Avdiskiy V.I. [17] and other researchers.

The risks of SIS operators and DFA exchange operators include, in addition to the risks of direct economic entities, also the risks of information systems in which digital assets are issued and exchanged.

Since the indicated risks, with the prevalence of unfavorable economic factors, are capable of generating threats to economic security and sustainable development, an economic entity, when carrying out transactions with DFA, should be guided by a riskoriented approach that allows predicting unfavorable outcomes. Popov E.V. defines as the main problem of ensuring economic security "the problem of" digital inequality ", the lack of its own element base, changes in the labor market, industrial espionage, manipulation of personal data and others." [18]

As directions for leveling threats to economic security when carrying out transactions with DFAs, business entities should take into account all risk factors, conduct their assessment and comprehensive analysis, on the basis of which choose the appropriate strategy from the four traditionally proposed in the theory of risk management: 1) risk diversification, assuming the formation of a multidisciplinary portfolio of CFA; 2) risk sharing, not only with partners, but also with SIS operators and DFA exchange operators; 3) risk insurance, i.e. the use of modern products in the insurance market, in particular hedging; 4) avoiding risk, implying refusal from transactions with risky CFA.

In the international practice of the Chartered Institute of Management Accountants (CIMA), it is proposed to use the so-called TARA risk management model, the

Table 2. Risks of transactions with digital financial assets.

\begin{tabular}{|c|c|c|c|}
\hline $\begin{array}{l}\text { The risks of the } \\
\text { CFA itself }\end{array}$ & $\begin{array}{l}\text { Risks of the CFA } \\
\text { issuer }\end{array}$ & $\begin{array}{c}\text { Risks of the SIS operator issuing the digital } \\
\text { asset }\end{array}$ & $\begin{array}{l}\text { Risks of the operator of the } \\
\text { exchange CFA }\end{array}$ \\
\hline $\begin{array}{l}\text { - the risk of price } \\
\text { changes, } \\
\text { - the risk of } \\
\text { insolvency of the } \\
\text { issuer, } \\
\text { - liquidity risk, } \\
\text { - the risk of non- } \\
\text { acceptance of the } \\
\text { CFA by the } \\
\text { exchange operator }\end{array}$ & $\begin{array}{l}\text { - risks of decreasing } \\
\text { financial results; } \\
\text { - loss of } \\
\text { competitiveness; } \\
\text { - reduction of sales } \\
\text { markets; } \\
\text {-risks of deteriorating } \\
\text { financial condition } \\
\text { - other risks }\end{array}$ & $\begin{array}{l}\text {-risks of loss of information stored in the ICS; } \\
\text {-risks of failure in the operation of } \\
\text { information technologies and technical means } \\
\text { of the information system; } \\
\text {-risks of providing false, incomplete and / or } \\
\text { misleading information; } \\
\text {-risks of violation by the operator of the rules } \\
\text { of the information system; } \\
\text {-risks of non-compliance of the information } \\
\text { system with the requirements of Law 259-FZ }\end{array}$ & $\begin{array}{l}\text { - risks of non-compliance with the } \\
\text { norms of Russian law; } \\
\text { - risks of a decrease in the value of } \\
\text { net assets; } \\
\text { - the risk of changes in the capital } \\
\text { structure; } \\
\text { - organizational risks in relation to } \\
\text { the head, chief accountant, head of } \\
\text { the ICS; } \\
\text { - risks of operational reliability, } \\
\text { etc. }\end{array}$ \\
\hline
\end{tabular}


Figure 1 TARA Risk Management Model CFA.

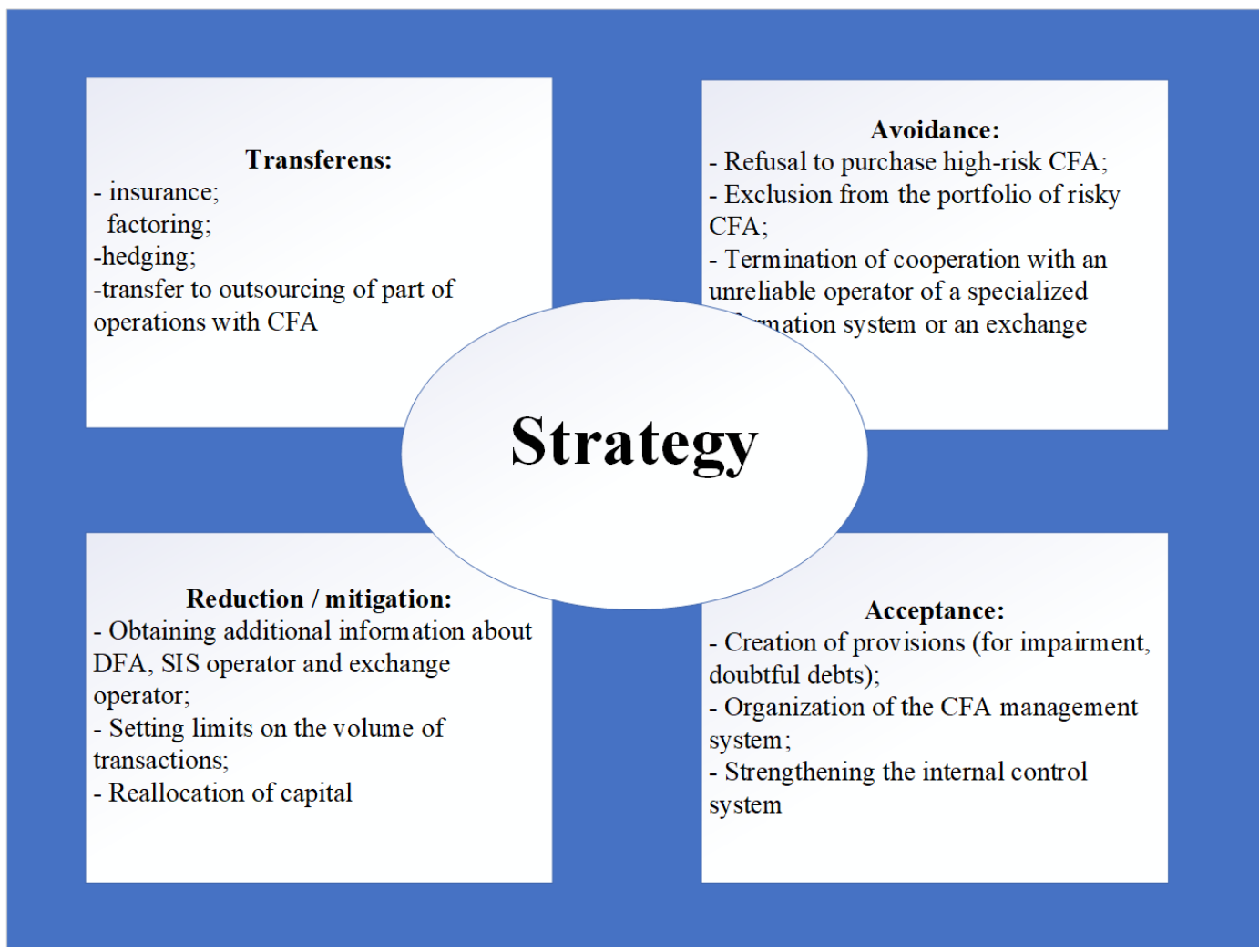

adaptation of which for operations with CFA is shown in Fig 1.

The use of this model allows a business entity to optimize the risk management process in relation to transactions with CFA, to neutralize threats to economic security and, thereby, to ensure sustainable development in the digital space.

\section{CONCLUSION}

Thus, the issues of ensuring economic security in the system of transactions with CFA considered in this article can be adopted by modern business entities when planning a management system for these facilities, leveling CFA risks and forming a sustainable development trend. At the same time, further areas of scientific research should include the theoretical and methodological substantiation of the methodology for carrying out operations with CFA within the framework of the current legislation, incl. its improvement, since the adopted Law 259-FZ outlined only the basic rules for the circulation of digital financial assets and clarified the procedure for interaction between the parties, however, a significant growth area is the development of guidelines and instructions in relation to these operations. The general digitalization of the Russian economy gives rise to new objects of civil rights and dictates new rules, the application of which by Russian business entities in order to enter world markets, increase competitiveness, and increase the efficiency of activities will increase the economic security of not only business entities, but also the national economy as a whole.

\section{REFERENCES}

[1] L.V. Sannikova, Yu.S. Kharitonova, Legal essence of new digital assets. In: Law, 9 (2018) pp. 86-95.

[2] V.A. Laptev, Digital Assets as Objects of Civil Rights, in Legal Science and Practice. In: Bulletin of the Nizhny Novgorod Academy of the Ministry of Internal Affairs of Russia, 2(42) (2018) pp. 199204. DOI: https://doi.org/10.24411/2078-53562018-10031.

[3] E.L. Sidorenko, Z. I. Khisamova, Russian concept of digital asset market regulation: realities and prospects. In: Law and Economics, 2 (2019) pp. 513.

[4] G.K. Dmitrieva, Digital Financial Instruments: Problems of Conflict Regulation. In: Actual Problems of Russian Law, 5(102) (2019) pp. 120128.

[5] Barney, Mauro and Franco Bartolini, ed. Watermarking systems development: securing digital assets and other applications. Crc Press, 2004.

[6] Austerbury, David. Digital asset management. Rutledge, 2012. 
[7] Collberg, Christian, et al. Towards the protection of digital assets. In: Intelligent Systems IEEE, 26.6 (2011) pp. 8-13. DOI: https://doi.org/10.1109/MIS.2011.106.

[8] A.K. Modenov, M.P. Vlasov, Economic security in the digital economy. In: St. Petersburg Economic Journal, 2 (2020) pp. 121-134. DOI: https://doi.org/10.24411/2307-5368-2020-00015.

[9] M.P. Vlasov, E.K. Torosyan, Zh.N. Zarubina, Issues of economic security of organizations with a single nature of production. In: St. Petersburg Economic Journal, 1 (2017) pp. 147-156.

[10] O.A. Mironova, Development of economic security as a science: problems and prospects. In: Innovative development of the economy, 2 (2019) pp. 332-338.

[11] E.S. Mityakov, S.N. Mityakov, Assessment of risks in the tasks of monitoring economic security. In: Proceedings of NSTU im. R.E. Alekseeva, 1(120) (2018) pp. 44-51.

[12] R.V. Dronov, A.A. Ananyev, Economic security is an important factor in the development of Eurasian integration projects. In: the VI International Economic Forum Eurasian Economic Perspective, pp. 23-28 (2019).

[13] G.E. Krokhicheva, E.L. Arkhipov, K.S. Zentsova, E.I. Novikova. In: Financial Security in the System of Economic Security, in KANT, 3(20) (2016) pp. 107-111.

[14] 14. M.M. Dolgieva, Digital Assets and Criminal Legislation of Russia. In: Legal Science and Practice: Bulletin of the Nizhny Novgorod Academy of the Ministry of Internal Affairs of Russia, 1(45) (2019) pp. 108-113. DOI: https://doi.org/10.24411/2078-5356-2019-10115.

[15] D.A. Gorulev, Economic security in the digital economy. In: Technical and technological problems of service, 1(43) (2018) pp. 77-84.

[16] V.M. Bezdenezhnykh, A.S. Rodionov, Proactive Risk-Based Approach in Scenario Planning for Business Entities. In: Economics. Taxes. No, really, 6 (2017) pp. 76-83.

[17] V.I. Avdiskiy, Risk management in the activities of business entities. In: Economics. Taxes. No, really, 4 (2013) pp. 4-12.

[18] E.V. Popov, K.A. Semyachkov, Problems of Economic Security of Society in the Context of Globalization. In: Economy of the Region, 14(4) (2018) pp. 1088-1101. 